\title{
National Vocational Qualifications in the Tourism and Hospitality Industry of Slovenia
}

\author{
Marija Rok \\ Faculty of Tourism Studies - Turistica, University of Primorska \\ Portoroz, Slovenia
}

\begin{abstract}
Hardly anybody would agree that the labour market satisfactorily meets the needs of the tourism and hospitality industry (THI). The THI worldwide faces the shortage of skilled labour force and the Slovenian THI is no exception. The problem persists in spite of various recruitment measures of employers, e.g. engaging migrant workforce, student work, black market, etc. The first aim of the paper was to explore the workforce needs of the THI with an emphasis on its unmet demands. The desk research revealed the mismatch between the supply and demand of the workforce on lower levels. Since the system of the National vocational qualifications (NVQ) is presumed beneficial for deficiencies of the labour market the second aim of the article was to explore the current state of the NVQ system in Slovenia and the selection of the existing NVQs in the THI in order to find out whether the number and structure of awarded NVQ certificates improved structural imbalances on the TH labour market. The author came to the conclusion that all forms of lifelong learning might contribute to improve the qualification structure of the labour force in the country provided that the employers overcome their distrust of the credibility and quality of the NVQs.
\end{abstract}

Keywords: National vocational qualification, tourism and hospitality industry, Slovenia, labour market, lifelong learning

\section{Introduction}

In the early $21^{\text {st }}$ century the concept of work-based learning and NVQs was widely accepted in education, learning as well as the economy of Slovenia. All forms of lifelong learning, i.e., formal, non-formal and informal learning have been recognized as crucial for the development of human resources. In order to maintain a competitive edge over the rivals businesses, industries and the society recognized the need to asses and verify knowledge and skills obtained in various forms of learning. Davies (1985) illustrated learning activities (Figure 1) in a circle containing all forms of learning and sequenced from informal (experiental learning, incidental learning), to non-formal and formal learning.

\section{Figure 1: Forms of learning}

The adoption of the National Professional Qualifications Act (2000) and the Lifelong Learning Strategy (2007) in Slovenia formed a legal base established to develop systems of assessing prior learning. This adoption raised great hopes about the quality of impacts on employability, employee promotion, wage levels, self-employment, etc.

The systems of assesing prior learning in Slovenia comprise:

Validation and certification of NVQs

Validation and verification of prior learning in secondary and tertiary education

Assessment of language learning (Slovenian, English, French, German, Italian and Hungarian) founded on national standards

Skills assessment on the basis of sectoral regulations

Skills assessment by employers, chambers and other associations 
Among them the first one is the most developed and sophisticated way of assessing non-formal and informal learning. It was raised under the auspice of the Ministry of labour, family social affairs and equal opportunities with the consensus of employers' associations, chambers, trade unions and the formal education system. It operates and is supervised by CPI Institute of the Republic of Slovenia for vocational education and training and RIC - National examination centre.

This paper has an aim to reveal the current state of the system of NVQ certifications in the THI in connection with its skill needs and its potentials. The secondary analysis of the existing data will disclose potentials of the NVQs to solve mismatches on the labour market.

\section{Theoretical background}

In Slovenia there are two systems leading towards vocations (Figure 2). The basis of vocational qualifications are occupational standards. They lead to either vocational educational programmes or to the catalogues of standards of NVQs (so called certification system). The left side is under the auspices of the Ministry of education and sport, the right under the auspices of the Ministry of Labour, family, social affairs and equal opportunities.

\section{Figure 2: The two paths to the same target}

While young people should attend formal educational programmes, the certification system is meant only for adults. Certificates of NVQs do not reward degrees, but candidates are rewarded with a vocational qualification. This system brings about other advantages for candidates too. Naylor (2004) claims that NVQs could also liberate and motivate individuals who had been previously unable to develop and could provide a practical and rewarding alternative to a purely academic route. The emphasis is on the fact that good quality assessors are essential for the enforcement of the NVQ certification system. Further, certificates of NVQ could solve a problem of drop-outs as well. Duvecot et al. $(2005,198)$ agreed: "The fact that Slovenia has got relatively high rates of drop-outs from the formal educational system, gives more value to the validation of experiential learning as a factor of national policy of improving the qualification structure of the labour force."

Thus certificates of $N V Q$ include as formally recognized competencies also knowledge, skills, know-how, values, and other competencies, obtained outside the formal system through various kinds of non-formal and informal learning. While in the past people learned all at schools, colleges and universities, that sufficed for their lifetime, concurrently, knowledge must be constantly upgraded, otherwise it is in danger of becoming dated. People learn in workplaces, through voluntary activities, hobbies, via the media, through self-study etc. Besides, ICT fosters and enables an interest and motivations in learning and self-learning. The society has to make this tacit knowledge more explicit, validate it and verify so that candidates can obtain formal proofs that they posess certain competencies. Their employability and competitiveness on the labour market will thus increase.

In the circumstances of the global market we face challenges through rapid economic, technological and social changes. In order to adapt to them some steps were taken in Slovenia, like the reform of vocational education and training, certification and the introduction of informal forms of education into the system of accrediting vocational qualifications. Thus since 2000 there is also a new opportunity to gain vocational qualifications in the certification system. Furthermore, the system of NVQs can adapt rapidly to the technological changes and changes in service activities as distinct to the school system (Drofenik, 2017). The area of tourism and hospitality awaited these opportunities with high expectations since the lack of personnel in this industry is a serious and permanent problem.

\section{Tourism in Slovenia}

In the year 2018 Slovenian tourism marked record numbers. The number of international arrivals continued to increse and Slovenia was yet again above the European average. In 2018 the country achieved 5,62 milion tourist arrivals and 15,29 overnight stays, which is $7 \%$ more arrivals and $8 \%$ more overnight stays than in 2017 (STO, 2019). There are 56.014 employees in tourism sector, their share thus achieving $6.5 \%$ of all employees. Slovenia's travel\& tourism competitiveness index (by WEF) in 2017 reached the ranking 41/139 countries. Although the growth of the tourism sector has been constantly accompanied by the demand for the qualified workforce, the lack of unskilled and skilled workers persists. As a highly labour intensive industry THI depends on the good quality personnel in order to perform good quality service (Rok and Mulej, 2014). Moreover, providing high-quality service to customers requires competent, motivated and devoted employees. Furthermore, the labour shortage has been evident worldwide since the 1980's (WTO, 1983) but the industry still keeps facing the same challenges. As Baum (2019) asserts work in the hospitality remain a persistent blemish 
with respect to one of the world's fast growing economic sectors. THI seems to have difficulties both in finding skilled employees and in keeping their existing employees in hand (Richardson, 2009). Authors agree that the THI is not a career choice for many young people but only a stop gap whilst looking for something better. Partly because hospitality work is considered low-skilled work, carrying social stigma whilst ignoring the fact that it involves soft skills and interactive service work, emotional involvement and physical embodiment (Duncan, Scott and Baum, 2013). Therefore, high staff turnover and poor image of hospitality work pose serious problems and challenges for employers and other decision makers in the THI. Can the system of NVQs certificates help make improvements in this area?

\section{Methodology}

The present survey seeks to answer the following research questions:

RQ1: What selection of qualifications does the system of certificating NVQs offer in the area of tourism?

$R Q 2$ : Does the selection of available NVQ certificates correspond with the unmet demands of the THI?

RQ3: In what ways is the real sector integrated in the system of certificating NVQs?

An analysis of the secondary data has been carried out, including firstly official statistical data collected by SURS (Statistical office of the Republic of Slovenia) and ESS (Employment service of Slovenia) in order to provide an overview of the labour supply and demand in THI. Further, databases of NRP (National Reference Point for Occupational qualifications Slovenia), NPK (NVQ), CPI (Institute for Vocational Education and Training) and RIC (National Examinations Centre) were surveyed. A strong foundation to this research project were also analyses carried out by ESS (2019), IMAD (Institute of Macroeconomic Analysis and Development) and CPI (Kunčič Krapež et al., 2017; Kunčič Krapež et al., 2014). Consequently, we have gathered, selected and compared all data concerning NVQs in the area of tourism and hospitality in relation to the labour market conditions and trends and could thus follow and evaluate the achievements of the system.

\section{Findings and discussion}

We started our research into the system of certifying NVQs by examining the structure of NVQs in the area of tourism and hospitality. We searched the data on catalogues of expertise and skills standards (NRP, NPK).

We identified altogether 26 NVQs, 9 in tourism (table 1) and 17 in hospitality (table 2).

\section{Table 1 National vocational qualifications in tourism}

\section{Table 2 National vocational qualifications in hospitality}

Additionally, we identified some interesting NVQs that are typical for other service industries but we meet such occupations in the THI as well. Thus we recognized NVQ Porter, NVQ Masseur, NVQ Pedicurist, NVQ Manicurist, NVQ Cake, bread and pasta maker in a traditional way, etc.

Surprisingly, we found out that NVQs on an entry level higher than VI. do not exist. The reason being is in the fact that the higher educational system opposes them. Their arguments that NVQ cerificates could undermine the traditional school system are present from the very launch of the NVQ system in 2002 in spite of the fact that it encompasses only adults. Therefore, it does not compete with the formal school system but complements it.

Next, we surveyed the situation in the labour market and noticed an upward drift in shortages of skilled workforce in several industries. IMAD $(2018,7)$ observed how businesses'vacancies match the supply of workforce in 2018 and found out that

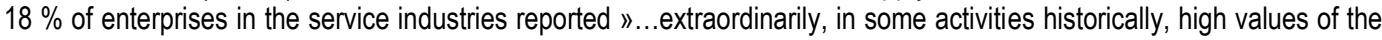
indicators of labour shortages and capacity utilisation«. However, the ESS survey (2019) reveals that enterprises in the THI forecast the $3,3 \%$ increase of employments for 2019 . The survey implies that $68,8 \%$ of employers report inability to fill vacancies, mostly for low-paid, physically demanding workplaces with unfavourable schedules. Analyses reveal that cooks (714), waiters (664), bartenders, fast food preparers and food servants were the most in-demand jobs in the THI in 2018. But the selection of NVQs shows that cooks and waiters are not included in the system of NVQs. Therefore, chances to solve shortages of skilled workforce in the THI are limited within the system of NVQs.

Further, we examined data of the Statistical office (SURS, 2019). They monitor the relation between job vacancies nad occupied posts in hospitality throughout the year (table 3). 


\section{Table 3 Job vacancies, occupied posts and rates, 2018}

As table 3 implies, job vacancies show fairly constant numbers and rates throughout the year in spite of the seasonality influence. Research (ESS, 2019) reveals that employers in the THI approach the problem of unmet vacancies diversly, either with their existing personnel (overtime work, retraining) or they search for workers abroad, use outsourcing or employment agencies. Some employers soften the requirements in job adverts or they choose not to hire and they rather reduce the service production. Unfortunately, the register of unemployed persons at the ESS is of no help to them, since many of the unemployed do not seek jobs actively, some of them have health problems or are too old for physically demanding post in the THI.

Further, we examined the statistics of issued NVQ certificates in the THI in order to observe their development (tables 4 and 5). Additionally, we wanted to find out how they match with the THI vacancies.

\section{Table 4 Number of awarded certificates in hospitality}

\section{Figure 3 Development of NVQs in hospitality 2002-2017 (awarded certificates)}

\section{Table 5 Number of awarded certificates in tourism}

\section{Figure 4 Development of NVQs in tourism 2002-2017 (awarded certificates)}

We noticed that some NVQs have no awarded certificates because either assessment institutions or licensed assessors have not been accredited yet. For some of the NVQs there is no interest among the potential candidates and obviously employers as well.

Table 5 and figure 4 imply a steady decrease in the number of awarded certificates in tourism but table 4 and figure 3 show a more dynamic drift in hospitality. The majority of certificates were awarded for the NVQ Cook assistant (727), half less for NVQ Diet cook (393) and less (26) for NVQ Waiter assistant. We discovered that the system of certifying NVQs enables employment of non-EU workers since the certificate holders can obtain work permissions. Shortages of cook assistants and waiter assistants can thus be solved by recruiting imigrants provided they are able to gain NVQ certificates through the processes of validation and verification of prior learning.

Interestingly, the number of issued certificates for NVQ Croupier decreased extremely and since 2012 there have not been awarded any. We found out that there are only two big employers in the area of gambling in Slovenia and they stimulated their employees to gain a certificate (and financed them). NVQ Croupier obviously reached its saturation point. On the other hand assessment organizations had high expectations for NVQ Tourism animator (17 accredited organizations) but proved unrealistic and interests of candidates and employers diminished.

We found out that in case that the NVQ certificate is required in recruiting procedures then it's establishment is secured. Examples of such legal requirements are for NVQ Masseur or NVQ Security Guard. Some NVQs enable holders to start their own business as it is the case of NVQ Herbalist. These are foundations for the success of some NVQs.

Furthermore, we examined the structure of the assessment institutions accredited for the validation and verification of NVQs in the THI (table 6).

\section{Table 6 Structure of the assessment organizations}

The assessment organizations are mostly from the education sphere. Unfortunately only few of them are from the real sector implying that the THI shows little interest in the system of NVQs. Very few of them encourage employees to participate in processes of obtaining certificates (Kunčič et al., 2017) let alone cover the costs for them. As analyses show (Rok, 2012) employers prefer school diplomas, hardly any of them provide initiatives for new NVQs, moreover, their acquaintance with the certification system is weak. Obviously, the promotion of the system is ineffective. They recruit mostly on the basis of evidence of formal education and they value past working experiences highly. Since NVQ certificates formalize working experience, apparently they are not informed.

This study does not go into details about the functioning of the system of NVQs, satisfaction of candidates and other stakeholders with the system. International evaluations (e.g. Canning, 2000) report that candidates spent more time collecting evidence and building their portfolio than preparing for and being assessed. Thus less than a quarter of their time 
was spent on acquiring new knowledge. Future research on the satisfaction of employers and employees with the NVQ system in Slovenia would be necessary since these are the key stakeholders and the development of the system depends on their engagement.

\section{Conclusion}

The system of certifying NVQs for the needs of the THI comprises $26 \mathrm{NVQs}$. Unfortunately their structure does not correspond with the needs of the THI. They do not provide qualifications for the most in-demand jobs, like waiters and cooks. On the other hand stakeholders demonstrate no interest for some NVQs like NVQ cheese sommelier. Obviously, the collection of NVQs was established without serious analyses of the needs of the THI, current and future ones.

Structural imbalances on the labour market can only partially be improved by introducing NVQs in the THI. Since the share of enterprises reporting a shortage of workers has recently risen substantially employers and other decision-makers have to find solutions for these deficits. Otherwise their competitiveness might drop and they might fall behind their rivals. Considering also unfavourable demographic trends and the ageing population labour shortages in the $\mathrm{TH}$ are going to arise.

The system of cerifying NVQs has to adapt to the needs of the THI, follow the trends and predict future job profiles. Thus it can gain advantage over the formal school system. Its strengths are in flexibility, quick reactions to market conditions and, above all, the NVQ system enables inclusion of one's prior learning in his formal qualification. All tacit knowledge that individuals accumulate throughout their life and career.

This desk research answered all the questions set in the research plan. We find the system of NVQs a new opportunity for recognizing competencies that were adopted in various circumstances and can thus be formalized. But if employers do not acknowledge certified NVQs the whole system might fail. The certification system of NVQs is based on trust. As Ivančič (2000) points out, the value of experiential and non-formal learning on the labour market (as well as in the formal education system) is not only an administrative and a technical problem, but first and foremost a problem of general trust. So far employers have shown mostly disbelief and doubts. We found out that they are not interested in acquiring accreditations for assessments (only one employer from the THI), they prefer diplomas and value highly only work experience. The fact that certificates are evidences of experiental learning, does not persuade them. They are involved in the process of preparing catalogues of expertise and skills standards but afterwards their participation is limited.

Nevertheless, stakeholders (CPI, RIC, ESS, assessment organizations, chambers) might contribute to the establishment of NVQs with intensive promotion and engagement in those NVQs that are connected with deficits on the labour market. Besides, they should participate in introducing new NVQs corresponding with the needs of the THI.

\section{References}

[1] Baum, T. (2019). Hospitality employment 2033: A backcasting perspective. International Journal of Hospitality Management, 76, 45-52.

[2] Canning, R. (2000). The rhetoric and reality of the professional competence-based vocational education in Scotland Res Papers Educ, 15(1). 69-93.

[3] CPI - Institute of the Republic of Slovenia for Vocational Education and Training (2019). Nacionalne poklicne kvalifikacije. Retrieved January 20, 2019, from: http://www.cpi.si/ nacionalne-poklicne-kvalifikacije.aspx.

[4] Davies, A. (1985). Defining Non-formal Education. In: Non-formal Vocational Training. Courier, 34, 23-26.

[5] Drofenik (2017). National vocational qualifications system. Ljubljana: CPI.

[6] Duncan, T., Scott, D.G. and Baum, T. (2013). The mobilities of hospitality work: an exploration of issues and debates. Annals of tourism research, 41, 1-19.

[7] Duvecot, R., Kees, S. and Paulusse, J. (2005). The unfinished story of VPL: Valuation and Validation of Prior Learning in Europe's learning countries. Utrecht: Foundation EC-VPL\& Kenniscentum EVC.

[8] ESS - Employment Service of Slovenia (2019). Labour market, analyses. Retrieved January 20, 2019, from: https://www.ess.gov.si.

[9] IMAD - Institute of Macroeconomic Analysis and Development of the Republic of Slovenia. (2018). Autumn forecast of economic trends 2018. Ljubljana: IMAD. 
[10] Ivančič, A. (2000). Feststellung der zuvor erbworbenen kenntnisse (zusammenfassung). In: Vocational education and training developments in Slovenia, Germany and in the Netherlands, documentation from two policy workshops, ed. Peter Grootings. Ljubljana: MŠŠ.

[11] Kunčič Krapež, B., Višekruna, T., Mažgon, J. and Makovec Radovan, D. (2017). Spremljava certifikatnega sistema NPK: kandidati v postopku preverjanja in potrjevanja nacionalnih poklicnih kvalifikacij. Ljubljana: CPI.

[12] Kunčič Krapež, B.,, Urh, V., Stopar, M., Štarkl, D. and Klemenčič, P. (2014). Spremljava certifikatnega sistemana treh strokovnih področjih: gostinstvo in turizem, gradbeništvo in kmetijstvo. Ljubljana: CPI.

[13] Lifelong learning strategy (2007). Ministry of Education, Science and Sport of Republic of Slovenia and the Educational Research Institute.

[14] National Professional Qualifications Act (2000). The Official Gazette of the Republic of Slovenia Ltd, no. 81/2000. Ljubljana.

[15] Naylor, S. M. (2004). National vocational qualifications (NVQs) from the candidate`s perspective. Radiography, $10,61-67$.

[16] NPK (2019). National Vocational Qualification catalogue. Retrieved January 20, 2019, from: http://www.npk.si.

[17] NRP - National Reference Point for Occupational qualifications Slovenia (2019). Databases. Retrieved January 22, 2019, from: http://www.nrpslo.org /index.aspx.

[18] Rok, M. and Mulej, M. (2014). CSR-based model for HRM in tourism and hospitality, Kybernetes, 43(3/4), 346362.

[19] Rok, M. (2012). Labour market skill deficiencies in the tourism and hospitality industry. Our economy: Journal of Contemporary Issues in Economics and Business, 58(3/4), 80-87.

[20] Richardson, S. (2009). Undergraduates' perceptions of tourism and hospitality as a career choice. International Journal of Hospitality Management, 28(3), 382-388.

[21] STO - Slovenian Tourist Board (2019). Tourism in numbers. Retrieved January 18, 2019, from: https://www.slovenia.info.

[22] SURS - Statistical office RS (2018). Labour market. Retrieved February 10, 2019, from: http://www.stat.si/statweb.

[23] WTTC - World Travel\&Tourism Council (2019). Travel \& Tourism Economic Impact 2018: Annual Update: Summary. Retrieved January 20, 2019, from: https://www.wttc.org/-/media/files/reports/economic-impactresearch/regions-2018/world2018.pdf.

[24] WTO - World Tourism organization (1983). Tourism and employment: enhancing the status of tourism professions. World Tourism Organization, Madrid, Spain.

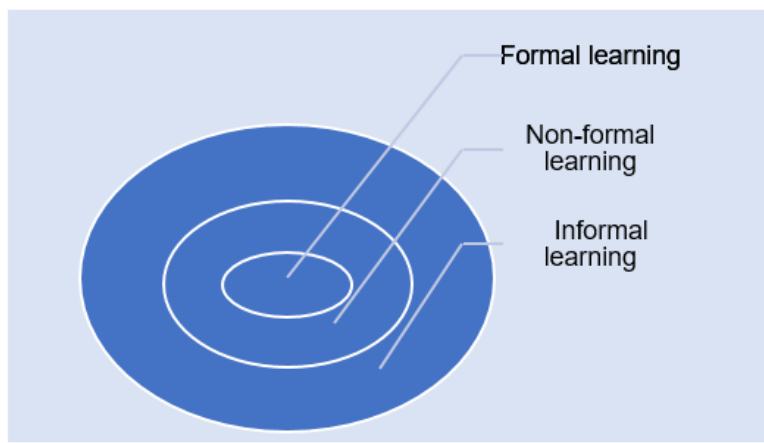

Figure 1 Forms of learning

Source: Davies, 1985 


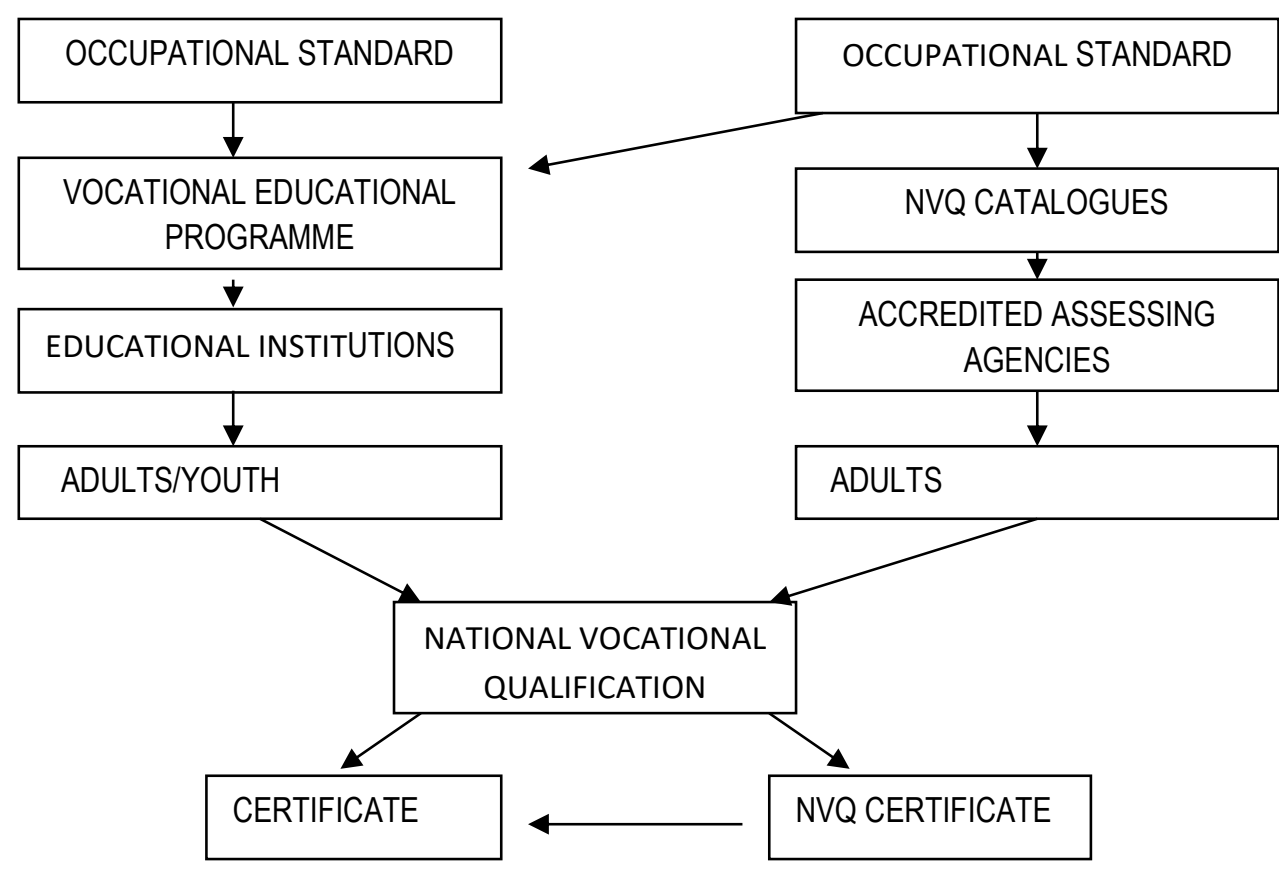

Figure 2 The two paths to the same target

Source: CPI, 2019

\begin{tabular}{|l|l|l|}
\hline & NVQ - TOURISM & Entry-level degree \\
\hline & NVQ Sauna Master & V. \\
\hline & NVQ Croupier & V. \\
\hline & NVQ Casino Cashier & V. \\
\hline & NVQ Gambling Machine Operator & V. \\
\hline & NVQ Tourism Informant & V. \\
\hline & NVQ Tourism Animator & V. \\
\hline & NVQ Travel Agency Manager & Vl. \\
\hline & NVQ Convention Events Organizer & Vl. \\
\hline & NVQ Destination Management Counsellor & Vl. \\
\hline
\end{tabular}

Table 1 National vocational qualifications in tourism

Sources: NRP (2019), NPK (2019)

\begin{tabular}{|l|l|l|}
\hline & NVQ - HOSPITALITY & Entry-level degree \\
\hline & NVQ Cook Assistant & III. \\
\hline & NVQ Waiter Assistant & Ill. \\
\hline & NVQ Chambermaid & Ill. \\
\hline & NVQ Room Supervisor & IV. \\
\hline & NVQ Pizza Baker & IV. \\
\hline & NVQ Barman & V. \\
\hline & NVQ Diet Cook & V. \\
\hline & NVQ Cheese Sommelier & V. \\
\hline & NVQ Wine Sommelier & V. \\
\hline & NVQ Catering Manager & V. \\
\hline & NVQ FOH Food Preparer & V. \\
\hline
\end{tabular}




\begin{tabular}{|l|l|l|}
\hline & NVQ Restaurant Dessert Preparer & V. \\
\hline & NVQ FOH Cook & V. \\
\hline & NVQ Reception Manager & Vl. \\
\hline & NVQ Hotel Housekeeper & Vl. \\
\hline & NVQ Small Hotel Manager & Vl. \\
\hline & NVQ Food and Bevarage Manager & Vl. \\
\hline
\end{tabular}

Table 2 National vocational qualifications in hospitality

Sources: NRP (2019), NPK (2019)

\begin{tabular}{|l|l|l|l|l|l|}
\hline & quarters & $2018 Q 1$ & $2018 Q 2$ & $2018 Q 3$ & $2018 Q 4$ \\
\hline HOSPITALITY & No. of job vacancies - total & 1827 & $2353 \mathrm{M}$ & 1840 & $1529 \mathrm{M}$ \\
\cline { 2 - 6 } & No. of occupied posts - total & 28550 & 29616 & 30155 & 30028 \\
\cline { 2 - 7 } & Job vacancy rate (\%) - total & 6.0 & 7.4 & 5.8 & 4.8 \\
\cline { 2 - 7 } & No. of job vacancies & 625 & 688 & $637 \mathrm{M}$ & $515 \mathrm{M}$ \\
\cline { 2 - 6 } & No. of occupied posts & 16405 & 17146 & 17628 & 17639 \\
\cline { 2 - 6 } & Job vacancy rate (\%) - total $^{*}$ & 3.7 & 3.9 & 3.5 & 2.8 \\
\hline
\end{tabular}

Table 3 Job vacancies, occupied posts and rates, 2018

* business entities that have at least 10 persons employed are included

Source: SURS (2019)

\begin{tabular}{|l|l|l|l|l|l|l|}
\hline Year & $\begin{array}{l}\text { NVQ Diet } \\
\text { Cook }\end{array}$ & $\begin{array}{l}\text { NVQ } \\
\text { Cook } \\
\text { Assistant }\end{array}$ & $\begin{array}{l}\text { NVQ Waiter } \\
\text { Assistant }\end{array}$ & $\begin{array}{l}\text { NVQ } \\
\text { Catering } \\
\text { Manager }\end{array}$ & $\begin{array}{l}\text { NVQ Wine } \\
\text { Sommelier }\end{array}$ & Total \\
\hline 2003 & 9 & $I$ & $/$ & 10 & 10 & 29 \\
\hline 2004 & 9 & $I$ & $/$ & 5 & 5 & 19 \\
\hline 2005 & 72 & $I$ & $I$ & 0 & 0 & 72 \\
\hline 2006 & 32 & $I$ & $I$ & 0 & 0 & 32 \\
\hline 2007 & 29 & $I$ & $/$ & 0 & 0 & 29 \\
\hline 2008 & 34 & 34 & 0 & 0 & 0 & 68 \\
\hline 2009 & 43 & 9 & 0 & 1 & 1 & 54 \\
\hline 2010 & 11 & 52 & 5 & 0 & 0 & 68 \\
\hline 2011 & 13 & 35 & 0 & 0 & 25 & 73 \\
\hline 2012 & 26 & 62 & 0 & 0 & 0 & 88 \\
\hline 2013 & 14 & 124 & 8 & 0 & 0 & 146 \\
\hline 2014 & 25 & 139 & 2 & 0 & 0 & 166 \\
\hline 2015 & 45 & 100 & 9 & 0 & 0 & 154 \\
\hline 2016 & 19 & 83 & 2 & 0 & 0 & 104 \\
\hline 2017 & 12 & 89 & 0 & 0 & 0 & 101 \\
\hline total & 393 & 727 & 26 & 16 & 41 & 1203 \\
\hline
\end{tabular}

Table 4 Number of awarded certificates in hospitality

Sources: NRP (2019), NPK (2019) 


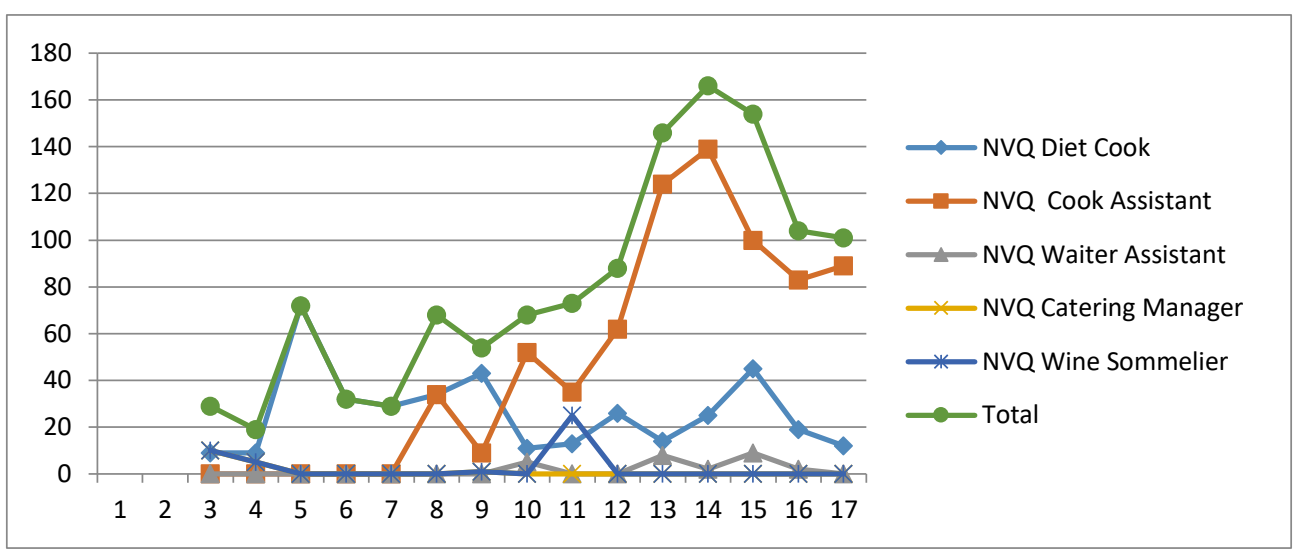

Figure 3 Development of NVQs in hospitality 2002-2017 (awarded certificates)

\begin{tabular}{|c|c|c|c|c|c|c|}
\hline$\frac{\text { NVQ }}{\text { Year }}$ & $\begin{array}{l}\text { NVQ } \\
\text { Croupier }\end{array}$ & $\begin{array}{l}\text { NVQ } \\
\text { Casino } \\
\text { Cashier }\end{array}$ & $\begin{array}{l}\text { NVQ } \\
\text { Gambling } \\
\text { Machine } \\
\text { Operator }\end{array}$ & $\begin{array}{l}\text { NVQ } \\
\text { Tourism } \\
\text { Informant }\end{array}$ & $\begin{array}{l}\text { NVQ Tourism } \\
\text { Animator }\end{array}$ & Total \\
\hline 2003 & 1 & 1 & 1 & 1 & 0 & 0 \\
\hline 2004 & 1 & 1 & 1 & 1 & 13 & 13 \\
\hline 2005 & 134 & 1 & 1 & 1 & 11 & 145 \\
\hline 2006 & 288 & 1 & 1 & 1 & 0 & 288 \\
\hline 2007 & 68 & 1 & 1 & 1 & 2 & 70 \\
\hline 2008 & 46 & 1 & 1 & 1 & 1 & 48 \\
\hline 2009 & 48 & 1 & 1 & 1 & 41 & 90 \\
\hline 2010 & 36 & 1 & 1 & 13 & 7 & 56 \\
\hline 2011 & 87 & 1 & 1 & 3 & 1 & 12 \\
\hline 2012 & 0 & 3 & 15 & 3 & 3 & 31 \\
\hline 2013 & 0 & 3 & 2 & 6 & 3 & 14 \\
\hline 2014 & 0 & 0 & 0 & 0 & 0 & 0 \\
\hline 2015 & 0 & 0 & 3 & 1 & 0 & 4 \\
\hline 2016 & 0 & 0 & 4 & 14 & 0 & 18 \\
\hline 2017 & 0 & 0 & 4 & 0 & 0 & 4 \\
\hline total & 635 & 6 & 28 & 42 & 82 & 793 \\
\hline
\end{tabular}

\section{Table 5 Number of awarded certificates in tourism}

Sources: NRP (2019), NPK (2019)

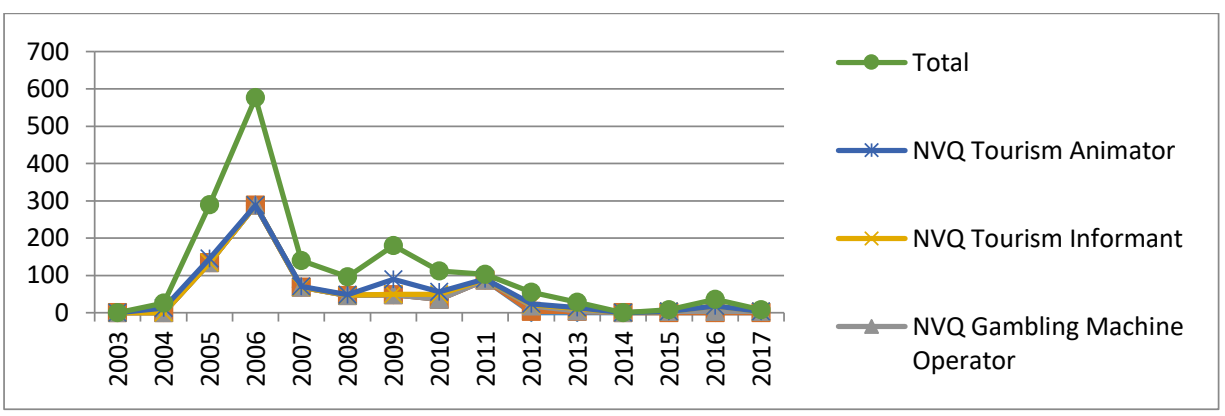

Figure 4 Development of NVQs in tourism 2002-2017 (awarded certificates) 


\begin{tabular}{|l|l|}
\hline Organization type & Number \\
\hline High school & 9 \\
\hline Vocational college & 4 \\
\hline Faculty & 1 \\
\hline Educational centre & 3 \\
\hline Adult education centre & 7 \\
\hline Chamber & 1 \\
\hline Bussiness & 1 \\
\hline Total & 26 \\
\hline
\end{tabular}

\section{Table 6: Structure of the assessment organizations}

Source: NRP (2019) 